\title{
Deleterious Effects of Food Habits in Present Era
}

Aliya Siddiqui**and Naga Anusha $\mathrm{P}^{2}$

${ }^{1}$ Department of Biotechnology, Chaitanya P.G. College, Kakatiya University, India

${ }^{2}$ Department of Biotechnology, Sri Y.N. College, Andhra University, India

\begin{abstract}
Food is any substance usually of plant or animal origin consumed to provide nutritional support for the body. It contains essential nutrients, such as carbohydrates, fats, proteins, vitamins, or minerals etc. Consuming healthy food like fresh fruits and vegetables gives the body strength and power to stay healthy without any infections and diseases. In spite of knowing the value of healthy food, most of the people prefer fast food which affects their health and lives. This Review Article deals with the Food and its Impact on Human Health, what are the side effects when food is taken in excess amounts and what might happens when it is not supplied to the body in enough quantities, what could be the problems which most of the people face if fast food or junk food is consumed in large or excess quantities. As fast food culture is an emerging trend among the younger generation and most of them may suffer with food allergies and various health problems when consumed on a regular basis. Fast food has become a prominent feature of the diet for most of the people in United States and increasing, throughout the world. Eating frequent fast food meals causes an individual to gain more weight and face an increased risk of developing disorders like Obesity, Type 2 Diabetes, Non alcoholic fatty liver disease and diseases related to heart etc. The ready availability, taste, low cost, marketing strategies and peer pressure make them popular with children and adolescents.
\end{abstract}

Keywords: Food; Fast food; Health effects; Diseases; Obesity; Heart disease; Type 2 Diabetes; Non alcoholic Fatty liver disease; Malnutrition; Food allergy

\section{Introduction}

The food we eat gives our bodies the "information" and the materials they need to function properly. If we don't get the right food and right information, at proper time our metabolic processes suffer and our health declines [1]. If we get too much food, or excess food or food that gives our bodies the wrong instructions, we can become overweight, or else undernourished, and could be at risk for the development of diseases and conditions, such as arthritis, diabetes, and heart disease. In short, what we eat is central to our health. The nutrients present in food enables the cells which are present in our bodies to perform their necessary functions [2]. "Nutrients are the nourishing substances in food that are essential for the growth, development and maintenance of the body functions [3]. If a nutrient is not present, its deficiency therefore leads to human health affect and may also decline in human health can be seen [4]. When nutrient intake does not regularly meet the nutrient needs dictated by the cell activity, the metabolic processes slow down or even stop. "Study after study shows that good food choices have a positive impact on health and poor diets have negative long-term effects [5]. A healthy diet gives the body required amount of nutrients it needs to perform, maintain function, and fight disease. Americans whose dietary pattern fit the USDA's Healthy Eating Index have a lower incidence of major chronic diseases [6]. Eating frequent fast food meals causes teens and young adults to gain more weight and face an increased risk of developing insulin resistance according to the results of a study funded by the National Heart, Lung, and Blood Institute (NHLBI). Obesity and diabetes are on the rise in people who take fast foods (like roasted food, fried food etc) frequently [7]. According to the study, men visit fast-food restaurants more frequently than women. It is important to watch carefully what you eat, especially at a fast-food restaurant, avoid heavy spicy food as it may affect your health [8]. One should know the nutritional content which is very important before having anything. Keep small size portions instead of consuming full amount of food once.

\section{Health effects caused by fast food}

A single meal won't wreck the diet, eating fast foods on a regular basis cause adverse health effects. It starts with putting on additional pounds due to excess and overconsumption of fat and/or sugar. Excess sodium intake, from highly salted foods, can cause disease over time as well. The negative impact on your metabolism can be exacerbated by deficiencies in vitamins and minerals. These may be lacking in fast-food meals, due to their greater amounts of injurious nutrients.

Weight gain: High calories from the fat and sugar in fast foods can cause weight gain over the years [9]. Eating fast foods more than twice a week may leads to a gain of 10 pounds in 15 years in the adolescents. Being overweight can lead to obesity, or a body mass index of 30 or more [10]. Obesity raises the risk for respiratory diseases, gall bladder disease, incontinence, arthritis and depression etc.

Insulin resistance: Fast foods don't cause diabetes directly; they do create body changes related to their nutritional content that may precede the disease. The young adults may also have increased incidence of insulin resistance, which is a major risk factor for type 2diabetes [11]. Most of the people with diabetes are overweight or obese. This chronic condition can lead to life-threatening complications, including heart attack and stroke [12].

High blood pressure: The nutritional imbalance in fast foods can raise your sodium levels above healthy limits. Sodium intake, which comes mainly from salt, influences your blood pressure. Developing hypertension, or high blood pressure, can also lead to fatal cardiac events such as heart attack [13].

Clogged arteries: Fast foods such as fried shrimp and cheeseburgers

${ }^{*}$ Corresponding author: Aliya Siddiqui, Department of Biotechnology, Chaitanya P.G. College, Kakatiya University, Warangal, India, E-mail: aliya.siddiqui53@gmail. com

Received November 10, 2011; Accepted December 20, 2011; Published December 25, 2011

Citation: Siddiqui A Anusha N (2012) Deleterious Effects of Food Habits in Present Era. J Aller Ther 3:114. doi:10.4172/2155-6121.1000114

Copyright: $\odot 2012$ Siddiqui A, et al. This is an open-access article distributed unde the terms of the Creative Commons Attribution License, which permits unrestricted use, distribution, and reproduction in any medium, provided the original author and source are credited. 
are high in fat content and cholesterol and can cause a buildup of plaque in arteries over time. This condition is called "atherosclerosis", it affects heart function and can also produce dangerous blood clots [14]. Atherosclerosis can also cause potentially fatal heart attacks and strokes, as well as reduced blood flow to the extremities that may result in gangrene and require amputation. The progression from atherosclerosis to coronary artery disease increases the risk of death.

\section{Major diseases due to high intake of junk food}

Body needs the proper nutrition to function properly. Many people eat more junk food than they should, due to the growing number of fast food restaurants and expanding portion sizes, this is injurious and dangerous to health, because a high intake of junk food can lead to obesity and also number of different diseases, including heart disease, the leading cause of death in America, according to the Centers for Disease Control and Prevention.

\section{Type 2 Diabetes}

The most common form of diabetes is Type 2 diabetes which is characterized by an inability to make or to use the hormone insulin properly [15]. This is a condition called "insulin resistance". Insulin resistance and progressive beta cell dysfunction may also be seen at times $[16,17]$. Diabetes affects $10.4 \%$ of people according to the 2006 WHO survey In Iraq [18]. It is common in people who are overweight because fat cells interfere with the body's ability to use insulin properly [19]. Food from outside especially the junk food contains high amounts of calories, fat and sugar. A high intake of these types of fats can increase the size and number of fat cells and promote weight gain. In some conditions, some people are able to stop taking medications for Type 2 diabetes after losing weight. Due to the increasing rates of childhood obesity an increasing number of children are being diagnosed with Type 2 diabetes [20]. More than 180 million people worldwide have diabetes according to World Health Organization (WHO) [21]. In order to prevent all these problems use of drugs is seen [22]. Diabetes mellitus is associated with an increased risk for a number of serious and sometimes life-threatening diseases such as coronary heart disease (CHD), cerebrovascular disease, and peripheral vascular disease [23, 24]. Heavy intake of alcohol may leads to cause of Type 2 Diabetes [25].

\section{Nonalcoholic fatty liver disease}

People who drink minimal amounts of alcohol are at a risk of causing Nonalcoholic fatty liver disease, characterized by the accumulation of fat in the liver [26]. Risk factors for developing nonalcoholic fatty liver disease are high cholesterol and high triglycerides, which develop from a high intake of saturated fat, trans fat, sugar and cholesterol, all of which are found in junk foods $[27,28]$. Malnutrition is also a risk factor for nonalcoholic fatty liver disease. Most junk foods contain a lot of calories and fat, but lacks important vitamins and minerals which are very essential for the body [29]. If you rely on junk food for most of your meals, you are at increased risk of becoming malnourished. People those with nonalcoholic fatty liver disease may experience fatigue, weight loss and pain in the upper right area of the abdomen, where the liver is located [30]. For some people, nonalcoholic fatty liver disease does not cause any serious complications. For others, the disease can lead to inflammation of the liver, which can lead to liver scarring and reduced liver function [31].

\section{Cancer}

Free radicals are unstable compounds by nature which are created in the body when exposed to toxins, like tobacco smoke, pollution and chemicals $[32,33]$. These free radicals can change the structure of cell membranes, promoting tumor formation and the development of cancer. Antioxidants are substances found in plant foods, like fruits, vegetables and whole grains, neutralize free radicals and prevent them from causing damage to cell membranes [34,35]. The more antioxidants consumed through diet, the more free radicals can be destroyed. High intake of junk food leaves less room for the healthy foods which provides antioxidants to the body. Good nutrition is especially important as a cancer prevention method in smokers.

\section{Heart disease}

Cardiovascular conditions that are life-threatening and associated with diet are coronary heart disease, hypertension and congestive heart failure etc. According to the Centers for Disease Control and Prevention, heart disease is the leading cause of death in the United States. High amount of oxycholesterol is present in Fried and processed food, particularly the fast food which most of the people prefers outside [36]. This oxycholesterol group shows greater deposition of cholesterol in the lining of arteries in those who usually have food outside rather than foods cooked at their home and develop a tendency for large deposit of cholesterol. These fatty deposits called as "atherosclerotic plaques". These "atherosclerotic plaques" increase the risk for heart attack and stroke.

\section{Coronary Heart Disease}

The most common form of heart disease is "Coronary Heart Disease", also called as "Coronary Artery Disease". It develops due to plaque buildup in arteries, which blocks the amount of oxygenated blood from reaching the heart, which increases the risk of a heart attack and death [37]. Eating junk foods that contain saturated or trans fats may increase the blood levels of total and low-density lipoprotein cholesterol, the "bad" cholesterol and decrease the blood levels of highdensity lipoprotein cholesterol, the "good" cholesterol. According to the research by Scientists in The Netherlands, eating high amounts of Trans fats contributes to the risk of coronary heart disease.

Coronary heart disease due to cholesterol: Cholesterol is a waxy, fat like substance which is used by the body to make bile and sex hormones. The persons with too much cholesterol have a risk of coronary heart disease and also other respiratory diseases $[38,39,40]$. Dietary cholesterol is found in dairy products, egg yolks, poultry, red meat and pork [41, 42]. Scientists at the University of Washington School of Medicine in Seattle found that there is a small association between dietary cholesterol and coronary heart disease and also found that reducing dietary cholesterol might reduce the risk of this heart condition.

\section{Atherosclerosis}

Atherosclerosis is a condition where large arteries get hardened due to plaque buildup. Plaque can rupture the artery and can cause blood clots that can block blood in the same artery or the clot can travel and get deposited in another area of your body, where it can block blood from flowing and cause a heart attack [43]. Atherosclerosis begins with elevated blood cholesterol, saturated and Trans fats from foods, and high blood pressure. Cells lining the interior of arteries become inflamed and can trigger a heart attack or stroke [44]. High Density Lipoprotein (HDL) is consistently associated with increased risk of atherosclerotic disease in United States [45].

Atherosclerosis due to Trans fat: In order to extend the shelf life of processed foods, such as breads, cakes, cookies, margarine and microwave popcorn manufacturers produce Trans fats (hydrogenated vegetable oils) for Industrial use in Food Industry [46, 47, 48, 49]. 
Trans fats are particularly used in fried foods such as doughnuts, french fries and onion rings etc by Fast-food restaurants. These Trans fats are unhealthy and can increase the risk of heart disease. However Studies concerning the pathogenesis of atherosclerosis entered a new phase of the 21st century [50].

\section{Heart failure}

Eating foods high in sodium and saturated and Trans fats may leads to an increase in blood pressure and cholesterol and also can elevate risk of heart failure, congestive heart failure, condition in which heart cannot pump enough blood to whole body [51]. Symptoms may include shortness of breath, fatigue and an irregular heartbeat. Overtime, arteries get weakened and unable to reverse the progression of disease. Heart failure can increase the risk of complications, including kidney and liver disease [52].

Heart failure due to saturated fat: Increase in the level of blood cholesterol, particularly, the (Low Density Lipoprotien) LDL cholesterol, the bad cholesterol results due to consuming saturated fat, found in meat, poultry and dairy products [53]. The body's ability to protect arteries from accumulation of plaque, which is a risk factor for heart disease, is inhibited by taking or eating one meal that is high in saturated fat content [54]. The Heart Research Institute in Sydney, Australia discovered that consuming saturated fat impairs the function of endothelial cells, which line and protect the interior of the arteries, and inhibits the ability of (High Density Lipoprotien) HDL, the good cholesterol, to reduce inflammation [55].

\section{Hypertension}

Hypertension is a cardiovascular condition of high blood pressure, which can increase the risk of coronary heart disease, heart failure, heart attack and stroke and also other kind of diseases [56]. Increasing the amount of salt intake from junk foods can increase blood pressure levels [57].

Hypertension due to intake of sodium: Consuming sodium in excess quantity can elevate the blood pressure and also increases the risk of congestive heart failure and stroke [58]. The heart unable to pump sufficient amounts of blood throughout the body in case of people with congestive heart failure as a result body fluids become backed up and one may suffer with breathing problems like shortness of breath, high blood pressure can extend from heart through blood vessels into the brain and cause a stroke, the third leading cause of death. One with high blood pressure should consume less than 1,500 mg of sodium per day.

\section{Obesity}

The foods we eat every day contribute to our well-being. Foods provide us with the required amount of nutrients we need for healthy bodies and the calories we need for energy [59]. If we eat too much, or in excess amounts, the extra food turns to fat and is stored in our bodies [60]. Over eating or excess eating regularly leads to gain weight, if we overeat regularly, we gain weight, and if we continue to gain weight, we may become obese [61]. Obesity means accumulation of excess fat in the body [62]. Obesity is considered as a chronic (long-term) disease, like high blood pressure or diabetes. It has many serious long-term consequences for your health, and it is the second leading cause of preventable deaths in the United States (tobacco is the first).

\section{Causes of Obesity}

Weight gain occurs due to eating of more calories than the body uses. If the food consumed provides more calories than the body needs, the excess food is converted to fat [63]. Fat cells increase in size initially, When they can no longer expand, they increase in number [64]. In weight loss, the fat cells decrease, but not the number of cells. Obesity, however, has many causes. The reasons for the imbalance between calorie intake and consumption vary by individual like Genes, Emotions, Environmental factors, Gender and Age [65]. Obesity can be associated with other eating disorders, such as binge eating or bulimia. If a person's bodyweight is at least $20 \%$ higher than it should be, he or she is considered as obese [66]. If your Body Mass Index (BMI) is between 25 and 29.9 you are considered overweight. If your BMI is 30 or over you are considered obese.

Body Mass Index (BMI): The BMI is a statistical measurement derived from height and weight of an individual. Though it is considered to be a useful way to estimate healthy body weight, it does not measure the percentage of body fat [67]. People become obese for several reasons, including:

Intake of Excess Calories: People are eating much more than they used to have earlier. This used to be the case in developed nations, but the trend has spread worldwide [68]. Despite of billions of dollars being spent on public awareness campaigns that attempt to encourage the people to eat healthily, the majority of them continue to overeat [69]. In $198014 \%$ of the adult population of the USA was obese; by 2000 the figure reached $31 \%$ (The Obesity Society). In the USA, the consumption of calories increased from 1,542 per day for women in 1971 to 1,877 per day in 2004. The figures for men were 2,450 in 1971 and 2,618 in 2004 [70]. Most of the increased food consumption has consisted of carbohydrates (sugars) [71]. Increased consumption of sweetened drinks has contributed significantly to the raised carbohydrate intake of most young American adults over the last three decades [72,73]. The consumption of fast foods has tripled over the same period. Leading a sedentary lifestyle, Lack of enough sleep, Lower rates of smoking (smoking suppresses appetite) and Medications that make patients put on weight [74]. Today's children, ages 8 to 18 , consume multiple types of media (often simultaneously) and spend more time ( 44.5 hours per week) in front of computer, television, and game screens than any other activity in their lives except sleeping which leads to Obesity [75].

Health risks associated with obesity: Bone and cartilage degeneration (Osteoarthritis), coronary heart disease, Gallbladder disease, High blood pressure (Hypertension), High total cholesterol, high levels of triglycerides (Dyslipidemia), Respiratory problems, several cancers, Sleep apnea, Stroke and Type 2 diabetes $[76,77,78]$.

When Food is not supplied in required quantities to the body then various diseases may occur and also leads to Malnutrition which could be fatal at times and leads to death.

\section{Malnutrition}

Consumption or Intake of unbalanced diet in which certain nutrients are lacking, in excess (too high an intake), or in the wrong proportions leads to a condition called "Malnutrition". A number of different nutrition disorders may arise, depending on which nutrients are under or overabundant in the diet [79]. According to World Health Organization malnutrition is the major and greatest single threat to the world's public health [80]. Mortality due to malnutrition accounted for $58 \%$ of the total mortality in 2006 . One in twelve people worldwide is malnourished. In 2006, more than 36 million died of hunger or diseases due to deficiencies in micronutrients [81]. The biggest contributor to child mortality, present in half of all cases is malnutrition according to the World Health Organization [82]. Every year six million children die of hunger. Underweight births and inter-uterine growth restrictions 
cause 2.2 million child deaths a year [83]. Other deficiencies, such as lack of vitamin A or zinc, for example, account for 1 million. Malnutrition in the first two years is irreversible. Malnourished children grow up with worse health and lower educational achievements [84]. Their own children also tend to be smaller. Malnutrition actually causes diseases as well, and can be fatal in its own right. Malnutrition increases the risk of infection and infectious disease; for example, it is a major risk factor in the onset of active tuberculosis [85]. Currently less than $10 \%$ of American college students report that they eat the recommended five servings of fruits and vegetables daily. Intake of fruits and fruit juices helps to maintain a good health $[86,87]$. "Better learning performance is associated with diet induced effects on learning and memory ability". Better nutrition has been shown to have an impact on spatial memory performance; a study showed those with higher blood sugar levels performed better on certain memory tests whereas in another study, those who consumed yogurt performed better on thinking tasks when compared to those who consumed caffeine free diet soda or confections [88].

Causes of Malnutrition: Malnutrition is a condition results due to the lack of essential nutrients, resulting in poorer health, may be caused by a number of conditions or circumstances [89]. Long term (chronic) malnutrition has widely spread simply because people do not have enough food to eat in many developing countries. Deriving too much of diet from a single source, such as eating almost corn or rice, can cause malnutrition. This may be due to lack of education about proper nutrition, or from having only access to a single food source $[90,91]$.

Poor diet: If a person does not eat enough food or proper food with required nutrients or if what they eat does not provide them with the nutrients they require for good health, they suffer from malnutrition [92]. Poor diet may be due to if the patient develops dysphagia (swallowing difficulties) because of an illness, or when recovering from an illness, they may not be able to consume enough of the right nutrients [93].

Mental health problems: some patients with mental health conditions, like depression, may develop eating habits which lead to malnutrition [94]. Patients with anorexia nervosa or bulimia may develop malnutrition because they are ingesting too little food.

Mobility problems: People with mobility problems may even suffer from malnutrition, because they either cannot get out enough to buy foods, or find preparing them too hard [95].

Stomach conditions and Digestive disorders: some people may eat properly, but their bodies cannot absorb the nutrients they need for good health. Some of the examples include patients with Crohn's disease or ulcerative colitis. Such patients may need to have part of the small intestine removed (ileostomy). Individuals who suffer from Celiac disease have a genetic disorder that makes them intolerant to gluten [96]. Patients with Celiac disease have a higher risk of damage to the lining of their intestines, resulting in poorer food absorption [97]. Patients who experience serious bouts of diarrhea and/or vomiting may lose vital nutrients and are at higher risk of suffering from malnutrition.

Alcoholism: An alcoholic is a person who suffers from alcoholism and the body is dependent on alcohol. Alcoholism is a chronic (longterm) disease. Alcoholism can develop gastritis, or pancreas damage in alcoholic individuals. Intake of Alcohol may also lead to anaphylactic reactions [98]. These problems also seriously weaken the body's ability to digest food, absorb certain vitamins, and produce hormones which regulate the metabolism [99]. Alcohol contains calories, which reduces the patient's feeling of hunger, so he/she may not eat enough proper food which supplies the body required and essential nutrients [100].
In poorer, developing nations malnutrition is commonly caused by:

Food shortages: Food shortages are a most significant cause of malnutrition in many parts of the world [101]. In poorer developing nations food shortages are mainly caused by a lack of technology which is needed for higher yields in modern agriculture, such as nitrogen fertilizers, pesticides and irrigation [102].

Food prices and food distribution: Approximately $80 \%$ of malnourished children live in developing nations that actually produce food in surpluses (Food and Agriculture Organization).

Lack of breastfeeding: Lack of breastfeeding, leads to malnutrition in infants and children $[103,104]$. In some parts of the world mothers still believe that bottle feeding is better for child.

Many tend to think malnutrition only in terms of hunger; however, overeating is also a contributing factor as well. Many parts of the world have access to a surplus of non-nutritious food, in addition to increased sedentary lifestyle.

\section{Food Allergy}

An abnormal response to food that is triggered by a specific reaction in the immune system and expressed by certain, often characteristic, symptoms is referred to as true "Food allergy". An adverse immune response to a food protein is called as Food Allergy. An adverse immunological reaction to a food is known as Food Allergy [105]. The components that are responsible for inciting an allergic reaction in food are called allergens. The most common allergic component in the food is a protein. When the body's immune system mistakenly identifies a protein as harmful then the allergy occurs [106]. These proteins usually resist the cooking heat, the stomach acid and the intestinal digestive enzymes. As a result, the allergens survive and cross the gastrointestinal lining, then enter the bloodstream, and target the organs, which ultimately lead to allergic reactions throughout the body [107]. These allergic reactions can range from mild to severe. Other types of reactions in response to foods which are not considered as food allergies include food intolerances (such as lactose or milk intolerance), food poisoning, and toxic reactions etc. Allergic responses include gastrointestinal and respiratory distress, dermatitis, including such life-threatening anaphylactic responses as biphasic anaphylaxis and vasodilatation, these type of allergies require immediate emergency intervention [108]. Everyone at some point could get affected by either food allergy or food intolerance. People those who have food allergies must identify and prevent them because, although mild but not severe, these reactions may cause devastating illness and, in some rare cases can be fatal. Though food allergy is not common but can be serious at times. Food allergy can be treated primarily by dietary avoidance. The leading causes of deadly allergic reactions like anaphylaxis are Tree nuts and peanuts. The foods that most often trigger allergic reactions in adults include, fish and shellfish, such as shrimp, lobster and crab, Peanuts, Tree nuts, such as walnuts, Eggs etc [109]. Problematic food for children includes eggs, milk (especially in infants and young children) and peanuts. Approximately 4 percent of adults and 6 to 8 percent of children are affected by food allergy in the United States (US). Latex could be cause of allergy in some individuals [110]. Food allergic reactions are the leading cause of emergency department visits for anaphylaxis in the US. Emergency treatment is the only therapy for food allergy in case of an accidental exposure that triggers a reaction. Patients and families must be vigilant about food allergens and the allergies caused by them. One has to avoid allergens in a variety of settings like home, restaurants, schools, camps, social gatherings etc. 


\section{Conclusion}

Consumption of fast food among people seems to have an adverse effect on dietary quality in ways that could increase risk for obesity, heart diseases etc. Consuming junk food or fast food on a regular basis leads to many health hazards. But bringing about changes in eating habits is not so easy. Fast food is a kind of addictive; in spite of knowing that it is unhealthy, most of the people get hooked on to it and continue consuming it in an uncontrolled way. The more it is consumed, the more difficult it would be to opt for healthy foods. Fast food all good tastes, except that it is not nutritionally balanced and, therefore, unhealthy in the long run if consumed on a regular basis leads to various disorders which may be fatal at times. To start with, a simple change that one could make is to successively reduce the frequency of eating fast food or junk food and eat more frequently home-cooked food, including plenty of fresh foods and vegetables. Fast food is deficient in dietary fiber and essential micro-nutrients like vitamins and minerals which are required for body to stay healthy. Making nutritional information available at fast food restaurants helps the consumers to order low calorie items which would be more beneficial and healthful.

\section{References}

1. Wang A, Molina G, Prima V, Wang KKW (2011) Anti-LPS Test Strip for the Detection of Food Contaminated with Salmonella and E. coli. J Microbial Biochem Technol 3: 026-029.

2. Atuobi C, Sakyi-Dawson E, Sefa-Dedeh S, Afoakwa EO, Budu AS (2011) Microstructural and Physico-Functional Characterization of Starches from Selected Cowpea (Vigna unguiculata L. Walp.) Varieties Developed for Pest and Disease Resistance. J Nutr Food Sci 1:104.

3. Turconi G (2011) Healthy Aging: Nutritional Intervention to Improve and Extend Quality of Life among Older People. J Nutr Food Sci 1:e101.

4. Wettstein MF, Ferreira Alves LN, Goldim JR (2011) Bioethics and Food Restrictions by Religious Motivations: Decision Making Processes in Health. J Clinic Res Bioeth 2:106

5. Turconi G, Simonetti P, Brusamolino A, Rondanelli M, Roggi C, et al. (2011) Nutritional and Plasma Antioxidant Status Assessment in a Group of Old Alzheimer's Inpatients. J Nutr Food Sci 1:101.

6. Coates A, Trounce MB (2011) FDA Food Safety Modernization Act: Is it Enough? J Bioterr Biodef 2:109.

7. Lasekan O, Juhari NH, Pattiram PD (2011) Headspace Solid-phase Microextraction Analysis of the Volatile Flavour Compounds of Roasted Chickpea (Cicer arietinum L). J Food Process Technol 2:112.

8. Adefegha SA, Oboh G (2010) Water Extractable Phytochemicals from Some Nigerian Spices Inhibit Fe2+- Induced Lipid Peroxidation in Rat's Brain - In Vitro. J Food Process Technol 2:104.

9. Emersson A, Nystrom FH, Lindstrom T (2010) Long-term increase of fat mass after a four week intervention with fast food based hyper-alimentation and limitation of physical activity. Nutr Metab 7: 68

10. Inagami S, Cohen DA, Brown AF, Asch SM (2009) Body mass index neighborhood fast food and restaurant concentration, and car ownership. J Urban Health 86: 683-95.

11. Esteghamati A, Nakhjavani M, Aminorroaya A, Aboutorabi R, M Niafar, et al (2011) Biphasic Insulin Aspart 30 (BIAsp 30) is Safe and Improves Glycaemic Control in Insulin Naïve Patients with Type 2 Diabetes. J Diabetes Metab 2:123.

12. Horita S, Seki G, Yamada H, Suzuki M, Koike K, et al. (2011) Insulin resistance, obesity, hypertension, and renal sodium transport. Int J Hypertens 391762.

13. KatholiRE, CouriDM (2011) Leftventricular hypertrophy: major risk factor in patients with hypertension: update and practical clinical applications. Int J Hypertens 495349

14. Getz GS, Reardon CA (2011) Apolipoprotein A-I and A-I mimetic peptides: a role in atherosclerosis. J Inflamm Res 4: 83-92.

15. Anwar AM, Mostafa MM, Nosir YFM (2010) Left Ventricular Remodeling in Diabetic Patients with and without Hypertension. J Diabetes Metab 1: 108.
16. Nichol A, Chandra Sekar M (2011) Successful Management of Extremely Insulin-Resistant Obese Diabetic Patient with Insulin Glargine, U-500 Regular Insulin and Pramlintide. J Diabetes Metab 2: 143.

17. Ali ZH (2011) Health and Knowledge Progress among Diabetic Patients afte Implementation of a Nursing Care Program Based on Their Profile. J Diabetes Metab 2: 121.

18. Mansour AA, Wanoose HL, Odaa AH (2011) A Three Year Cohort Prospective Type 2 Diabetes Control Study in Basrah. J Diabetes Metab 2: 119.

19. Shanker JH, Mahmood SE, Joshi MC, Shaifali I (2011) Obesity Indices amongst Diabetics in an Urban Population of Western Nepal. J Diabetes Metab 2: 134.

20. Kamoi K, Ohara N, Tomoo I, Shinozaki Y, Furukawa K (2011) Normal Response of Active GLP-1 like Substances Level to Test Meal in Non-Obese Type 2 Diabetic Japanese Patients with Complications and Receiving Treatments. J Diabetes Metab 2: 147

21. Mungrue K, Roper LA, Chung T (2011) Assessment of Weight Loss in the Management of Patients with Type 2 Diabetes Mellitus in Primary Care in Trinidad. J Diabetes Metab 2: 120.

22. Fouqueray $P$, Leverve $X$, Fontaine $E$, Baquié $M$, Wollheim $C$, et al. (2011) Imeglimin - A New Oral Anti-Diabetic that Targets the Three Key Defects of type 2 Diabetes. J Diabetes Metab 2: 126.

23. Abougalambou SSI, Hassali MA, Sulaiman SAS, Abougalambou AS (2011) Prevalence of Vascular Complications among Type 2 Diabetes Mellitus Outpatients at Teaching Hospital in Malaysia. J Diabetes Metab 2: 115.

24. Belmokhtar F, Belmokhtar R, Charef M (2011) Risk Factors Associated With Type 2 Diabetes Mellitus in West Region of Algeria, Maghnia. J Diabetes Metab 2: 148.

25. Li H, Wang G, Wang A, Tong W, Zhang Y (2011) Alcohol Consumption and Risk of Type 2 Diabetes in Mongolian Population, Inner Mongolia, China. J Diabetes Metab 2: 116.

26. Khosravi S, Alavian SM, Zare A, Daryani NE, Fereshtehnejad SM, et al. (2011) Non-alcoholic fatty liver disease and correlation of serum alanin aminotransferase level with histopathologic findings. Hepat Mon 11: 452-458.

27. Castellanos MI, Seijas OR, González D, Ronquillo M, del Rosario Abreu M, et al. (2011) Immune Alterations in Liver Cirrhosis: Its Relationship with Etiology, Child Pugh Stage and Malnutrition. J Nutrition Disorder Ther 1:101.

28. Dhibi M, Brahmi F, Mnari A, Houas Z, Chargui I, et al. (2011) The intake of high fat diet with different trans fatty acid levels differentially induces oxidative stress and non alcoholic fatty liver disease (NAFLD) in rats. Nutr Metab 8: 65.

29. Barchetta I, Angelico F, Del Ben M, Baroni MG, Pozzilli P (2011) Strong association between non alcoholic fatty liver disease (NAFLD) and low $25(\mathrm{OH})$ vitamin $D$ levels in an adult population with normal serum liver enzymes. BMC Med 9: 85.

30. Rahimi AR, Daryani NE, Ghofrani H, Taher M, Pashaei MR et al (Jun, 2011) The prevalence of celiac disease among patients with non-alcoholic fatty liver diseasein Iran. Turk J Gastroenterol 22: 300-304.

31. El-Koofy NM, El-Karaksy HM, Mandour IM, Anwar GM, El-Raziky MS, et al. (2011) Genetic polymorphisms in non-alcoholic fatty liver disease in obese Egyptian children. Saudi J Gastroenterol 17: 265-270.

32. Mwenifumbo JC, Tyndale RF (2010) DSM-IV, ICD-10 and FTND: Discordant Tobacco Dependence Diagnoses in Adult Smokers. J Addict Res Ther 2: 105.

33. Yu Y, Yang M, Sansgiry SS, Essien EJ, Abughosh S (2011) Beliefs in Effectiveness of Various Smoking Cessation Interventions among Chinese Adult Smokers. Epidemiol 1: 106

34. Durlu-Özkaya F, Özkaya Mt (2011) Oleuropein using as an Additive for Feed and Products used for Humans. J Food Process Technol 2: 113

35. Sopie Salomé YE, Laurent KK, Pierre Irénée BJ, Patrice K, Hilaire KT (2011) Comparison of Pineapple Fruit Characteristics of Plants Propagated in Three Different Ways: By Suckers, Micropropagation and Somatic Embryogenesis. J Nutr Food Sci 1: 109

36. Zaidi R, Rawat PR (2011) Identification of Heterocyclic Amines in Indian Home Cooked and Commercially Available Meat Foods. J Nutr Food Sci 1: 107.

37. Huffman FG, Vaccaro JA, Nusrath NS, Zarini GG (2011) The Effect of Carbohydrate Amount, Quality and Type on Arterial Pulse Pressure in CubanAmericans with and Without Type 2 Diabetes. J Nutr Food Sci 1: 106. 
38. Ramos-Jiménez A, Hernández-Torres RP, Wall-Medrano A (2011) Hatha Yoga Program Determinants on Cardiovascular Health in Physically Active Adult Women. J Yoga Phys Therapy 1: 103.

39. Nakagami T, Yamamoto Y, Fukushima S, Oya J, Iwamoto $Y$, et al. (2011) Assessment of Cholesterol Absorption and Synthesis in Japanese Patients with Type-2 Diabetes and Lipid-Lowering Effect of Ezetimibe. J Diabetes Metab 2: 139 .

40. Míguez MJ, Rosenberg R, Burbano X, Malow R (2011) Cholesterol as a Mediator of Alcohol-Induced Risks for Respiratory Disease Hospitalizations among People Living With HIV. J AIDS Clinic Res S1: 001.

41. Kizil M, Oz F, Besler HT (2011) A Review on the Formation of Carcinogenic/ Mutagenic Heterocyclic Aromatic Amines. J Food Process Technol 2: 120.

42. Wang DY, Liu F, Zhu YZ, Xu WM (2011) Changes of Phospholipids in Duck Muscle by Different Heating Methods. J Food Process Technol 2: 121

43. Guntheroth WG (2010) Increased Pulse Pressure Causes Vascular Injury in Pulmonary and Systemic Arteries. Decreasing the Pulsatility with Banding and Vasodilators Can Stabilize Pulmonary Hypertension. J Clinic Experiment Cardiol 1: 107

44. Genel S, Lucia S, Bogdan B, Maria S, Liana KS, et al. (2011) Therapeutical Approach of Arterial Hypertension. Pharm Anal Acta 2: 108e.

45. Calle MC, Vega-López S, Segura-Pérez S, Volek JS, Pérez-Escamilla R, et al. (2010) Low Plasma Hdl Cholesterol and Elevated C Reactive Protein further Increase Cardiovascular Disease Risk in Latinos with Type 2 Diabetes. J Diabetes Metab 1: 109

46. Khan MA, Semwal AD, Sharma GK, Mahesh C, Nataraj S, et al. (2011) Development and Evaluation of Long Shelf-Life Ambient Stable Chapaties Without The Use of Chemical Preservatives. J Food Process Technol 2: 107.

47. Aberoumand A (2011) Protein, Fat, Calories, Minerals, Phytic acid and Phenolic In Some Plant Foods Based Diet. J Food Process Technol 2: 114

48. Balaswamy K, Rao PP, Nagender A, Satyanarayana A (2011) Preparation of Sour Grape (Vitis Vinifera) Beverages and Evaluation of their Storage Stability. J Food Process Technol 2: 116

49. Jambrak AR (2011) Experimental Design and Optimization of Ultrasound Treatment of Food Products. J Food Process Technol 2: 102e.

50. Jawien J (2011) Mouse Experimental Models of Atherosclerosis in Pharmacology. J Clinic Experiment Cardiol S1: 001.

51. Angela B, Laurian V, Sorin L, Chira M, Gabriel S (2011) Carvedilol among Pediatric Patients with Congestive Heart Failure. Pharm Anal Acta 2: 104e

52. Shi G, Cui Q, Zhang Y (2009) MicroRNA Set: A Novel Way to Uncover the Potential Black Box of Chronic Heart Failure in MicroRNA Microarray Analysis. J Comput Sci Syst Biol 2: 240-246.

53. Nikoo M, Ghomi MR, Rahimabadi EZ, Benjakul S, Javadian B (2010) The Effects of Deep-Frying, Refrigerated Storage and Reheating on the Fat Content, Oxidation and Fatty Acid Composition of the Fish Rutilus frisii kutum. J Food Process Technol 1:103.

54. Matthäus B, Özcan MM (2011) Determination of Fatty Acid, Tocopherol, Stero Contents and 1,2- and 1,3-Diacylglycerols in Four Different Virgin Olive Oil. J Food Process Technol 2: 117

55. Li R, Chao H, Ko KWS, Cormier S, Dieker C, et al. (2011) Gene Therapy Targeting LDL Cholesterol but not HDL Cholesterol Induces Regression of Advanced Atherosclerosis in a Mouse Model of Familial Hypercholesterolemia. J Genet Syndr Gene Ther 2: 106.

56. Seck SM, Cisse MM, Ka EF, Diallo I, Gueye S, et al. (2011) Hypertension in Black Africans with Autosomal Polycystic Kidney Disease. J Nephrol Therapeutic 1: 102

57. Majithia R, Koch TR (2011) Our Obesity Crisis Requires The Development of New, Widely Available Options:Can Yoga Function In A Major Role? J Yoga Phys Therapy 1: e102.

58. Shi Y, de Groh M, Morrison H, Robinson C, Vardy L (2011) Dietary sodium intake among Canadian adults with and without hypertension. Chronic Dis Can 31: $79-87$.

59. Ranieri SC, Fusco S, Panieri E, Labate V, Mele M, et al. (2010) Mammalian lifespan determinant p66shcA mediates obesity-induced insulin resistance. Proc Natl Acad Sci USA 107: 13420-13425.
60. Mrudula T, Ghafoorunissa, Saravanan N, Reddy GB (2011) Effects of Prenatal and Postnatal Dietary Polyunsaturated Fatty Acids on Retinal Fatty Acid Composition and Gene Expression in Adult Rat. J Nutr Food Sci 1: 102.

61. Gittelsohn J, Wolever TM, Harris SB, Harris-Giraldo R, Hanley AJ, et al (1998) Specific patternsof food consumption and preparation are associated with diabetes and obesity in a Native Canadian community. J Nutr 128: 541-547.

62. Kelley DE, Mandarino LJ (2000) Fuel selection in human skeletal muscle in insulin resistance: a reexamination. Diabetes 49: 677-683.

63. Steyn NP, Labadarios D, Nel JH (2011) Factors which influence the consumption of street foods and fast foods in South Africa-a national survey. Nutr J 10: 104

64. Takasaki S (2011) Mitochondrial Haplogroups Associated with Japanese Centenarians, Alzheimer's Patients, Parkinson's Patients, Type 2 Diabetes Patients, Healthy Non-Obese Young Males, and Obese Young Males . J Proteomics Bioinform 4: 106-112.

65. Herrera BM, Lindgren CM (2010) The genetics of obesity. Curr Diab Rep10: 498-505.

66. Ylihärsilä H, Kajantie E, Osmond C, Forsén T, Barker DJ, et al. (2008) Body mass index during childhood and adult body composition in men and women aged 56-70 y. Am J Clin Nutr 87: 1769-75.

67. Boffetta P, McLerran D, Chen Y, Inoue M, Sinha R (2011) Body mass index and diabetes in Asia: a cross-sectional pooled analysis of 900,000 individuals in the Asia cohort consortium. PLoS One 6: e19930.

68. Alves JG, Falcão RW, Pinto RA, Correia JB (2011) Obesity patterns among women in a slum area in Brazil. J Health Popul Nutr 29: 286-289.

69. Duffey KJ, Popkin BM (2011) Energy density, portion size, and eating occasions: contributions to increased energy intake in the UnitedStates, 19772006. PLoSMed 8: e1001050.

70. Lin H, Bermudez OI, Tucker KL (2003) Dietary patterns of Hispanic elders are associated with acculturation and obesity. J Nutr 133: 3651-3657.

71. Drewnowski A, Specter SE (2004) Poverty and obesity: the role of energy density and energy costs. Am J Clin Nutr 79: 6-16.

72. James W. Anderson, MD, FACN, CNS and Katy Patterson, BS (June 2005) snack foods: comparing nutrition values of excellent choices and "junk foods". J Am Coll Nutr 24: 155-156

73. FisterK (2005) Junk food advertising contributes to young Americans' obesity. BMJ 331: 1426.

74. Cavallo DA, Smith AE, Schepis TS, Desai R, Potenza MN (2010) Smoking expectancies, weight concerns, and dietary behaviors in adolescence. Pediatrics 126: e66

75. Sugarman SD, Sandman N (2008) Using performance-based regulation to reduce childhood obesity. Aust New Zealand Health Policy 5: 26.

76. Gayes JM (2011) Obesity, Obstructive Sleep Apnea and the "HELP" Position. $J$ Anesthe Clinic Res 2: 115.

77. Lavoie M, Rabasa-Lhoret R, Ziai S, Lavoie J (2011) Blood Glutathione Peroxidase Activity in Relation with the Risk of Cardiovascular Diseases in Obese Women. J Diabetes Metab 2: 136

78. Martocchia A, Toussan L, Stefanelli M, Falaschi GM, Comite F, et al. (2011) Association of Severity of Osteoarthritis and Carotid Atherosclerosis in Patients with Metabolic Syndrome. Rheumatology 1:105.

79. Mondal D, Minak J, Alam M, Liu Y, Dai J, et al. (2011) Contribution of Enteric Infection, Altered Intestinal Barrier Function, and MaternalMalnutrition to Infant Malnutrition in Bangladesh. Clin Infect Dis.

80. Aziz EF, Javed F, Pratap B, Musat D, Nader A (2011) Malnutrition as assessed by nutritional risk index is associated with worse outcome in patients admitted with acute decompensated heart failure: an ACAP-HF data analysis. Heart Int 6: e2.

81. Sharghi A, Kamran A, Faridan M (2011) Evaluating risk factors for proteinenergy malnutrition in children under the age of six years: a case-control study from Iran. Int J Gen Med 4: 607-611.

82. Irena AH, Mwambazi M, Mulenga V(2011) Diarrhea is a Major killer of Children with Severe Acute Malnutrition Admitted to Inpatient Set-up in Lusaka, Zambia. Nutr J 10: 110.

83. Gathara D, Opiyo N, Wagai J, Ntoburi S, Ayieko P (2011 Nov 11) Quality of 
hospital care for sick newborns and severely malnourished children in Kenya: A two-year descriptive study in 8 hospitals. BMC Health Serv Res 11: 307

84. Singh A, Pathak PK, Chauhan RK, Pan W ( 2011) Infant and child mortality in India in the last two decades: a geospatial analysis. PLoS One 6: e26856.

85. Sarin R, Vohra V, Sachdeva R, Sachdeva S (2011) Magnitude of malnutrition amongst hospitalized TB patients. Lung India 28: 231-232.

86. Sevda SB, Rodrigues L (2011) Fermentative Behavior of Saccharomyces Strains During Guava (Psidium Guajava L) Must Fermentation and Optimization of Guava Wine Production. J Food Process Technol 2: 118.

87. Mansouri YS, Khazaei J, Hassan Beygi SR, Mohtasebi SS (2010) Statistical Modeling of Pomegranate (Punica granatum L.) Fruit with Some Physical Attributes. J Food Process Technol 1: 102

88. Demarin V, Lisak M, Morović S (2011) Mediterranean diet in healthy lifestyle and prevention of stroke. Acta Clin Croat 50: 67-77.

89. Silveira KB, Alves JF, Ferreira HS, Sawaya AL, Florêncio TM (2010) Association between malnutrition in children living in slums, maternal nutritional status, and environmental factors. J Pediatr 86: 215-220.

90. Nagendra Prasad MN, Sanjay KR, Shravya Khatokar M, Vismaya MN Nanjunda Swamy S (2011) Health Benefits of Rice Bran - A Review. J Nutr Food Sci 1:108.

91. Koskinen HI (2011) Nonverbal Communication between Veterinary Students and their Teachers in Food Animal Practice. J Veterinar Sci Technol S4:002.

92. Andres E, Serraj K, Mecili M, Kaltenbach G, Vogel T (2010) The Syndrome of Food-Cobalamin Malabsorption: A Personal View in a Perspective of Clinical Practice. J Blood Disord Transfus 2:108.

93. Prematta T, Kunselman A, Ghaffari G (2011) Comparison of Food and Aeroallergen Sensitivity between Adults and Children with Eosinophilic Esophagitis. J Aller Ther S3:001.

94. Wachs TD (2009) Models linking nutritional deficiencies to maternal and child mental health. Am J Clin Nutr. 89: 935-939.

95. Milaneschi $Y$, Tanaka T, Ferrucci L (2010) Nutritional determinants of mobility. Curr Opin Clin Nutr Metab Care 13: 625-629.

96. Freeman HJ (2010) Hepatic manifestations of celiac disease. Clin Exp Gastroenterol 3: 33-39.

97. Murphy JL, Badaloo AV, Chambers B, Forrester TE, Wootton SA (2002)
Maldigestion and malabsorption of dietary lipid during severe childhood malnutrition. Arch Dis Child 87: 522-525.

98. J, Khan D (2010) Remission of Anaphylactic Reaction to Alcohol. J Aller Ther $1: 104$.

99. Fernández-Bañares $F$, Monzón $H$, Forné $M$ (Oct, 2009) A short review of malabsorption and anemia. World J Gastroenterol 15: 4644-4652.

100.Payne PR (1975) Safe protein-calorie ratios in diets. The relative importance of protein and energy intake as causal factors in malnutrition. AmJ Clin Nutr 28: 281-286.

101. Motarjemi Y, Käferstein F, Moy G, Quevedo F (1993) Contaminated weaning food: a major risk factor for diarrhoea and associated malnutrition. Bull World Health Organ 71: 79-92.

102. Woods J, Williams A, Hughes JK, Black M, Murphy R (2010) Energy and the food system. Philos Trans R Soc Lond B Biol Sci. 365: 2991-3006.

103. Victora CG, Fuchs SC, Kirkwood BR, Lombardi C, Barros FC (1992) Breastfeeding, nutritional status, and other prognostic factors for dehydration among young children with diarrhoea in Brazil. Bull World Health Organ 70: 467-475.

104. Chisti MJ, Salam MA, Smith JH, Ahmed T, Ashraf H (2011) Impact of lack of breast feeding during neonatal age on the development of clinical signs of pneumonia and hypoxemia in young infants with diarrhea. PLoS One 6: e25817.

105. Kung SJ (2011) Food Allergy in Sub-Saharan Africa. J Aller Ther S3:002.

106. Gregersen K, Valeur J, Lillestøl K, Frøyland L, Araujo P (2011) Subjective food hypersensitivity: assessment of enterochromaffin cell markers in blood and gut lavage fluid. Int J Gen Med 4: 555-560.

107. YuLC (2012) Intestinal epithelial barrier dysfunctionin food hypersensitivity. J Allergy 596081.

108. Solé D, Ivancevich JC, Borges MS, Coelho MA, Rosário NA (2011) Anaphylaxis in Latin American children and adolescents: The Online Latin American Survey on Anaphylaxis (OLASA). Allergol Immunopathol.

109. Otsu K, Dreskin SC (2011) Peanut allergy: an evolving clinical challenge. Discov Med1 2: 319-328.

110. Pivaral CEC (2011) Is Natural Latex an Important Cause of Allergy? JAller Ther 2:102e. 